\title{
A Simple and Rapid Extraction for Gas Chromatographic Determination of Thiabendazole and Imazalil Residues in Lemons
}

\author{
Sandro Navickiene and Maria Lúcia Ribeiro* \\ Instituto de Química, Universidade Estadual Paulista, CP 355, 14801-970 Araraquara - SP, Brazil
}

\begin{abstract}
Um método rápido e eficiente é descrito para a análise de resíduos de tiabendazol e imazalil em limão (casca e polpa). O procedimento é baseado numa extração com hexano:acetato de etila (1:1, v/v) e análise por cromatografia a gás com detector termiônico específico. A possibilidade do efeito de matriz foi investigada. Os valores de recuperação média de 8 análises de amostras de limão fortificadas variaram de $79 \%$ a $109 \%$, com valores de desvio padrão relativo entre $2,4 \%$ e $12,8 \%$. Os limites de detecção e de quantificação do método foram $0,2 \mathrm{mg} \mathrm{kg}^{-1} \mathrm{e} 0,5 \mathrm{mg} \mathrm{kg}^{-1}$, respectivamente.
\end{abstract}

A rapid and efficient method is described for the determination of thiabendazole and imazalil residues in lemons (peel and pulp). The procedure is based on the extraction with an hexane:ethyl acetate mixture $(1: 1, \mathrm{v} / \mathrm{v})$ and gas chromatographic analysis using thermionic specific detection (TSD). The possibility of matrix effect was also studied. Mean recoveries from 8 replicates of fortified samples ranged from $79 \%$ to $109 \%$, with relative standard deviation values between $2.4 \%$ to $12.8 \%$. The detection and quantification limits of the method were $0.2 \mathrm{mg} \mathrm{kg}^{-1}$ and $0.5 \mathrm{mg} \mathrm{kg}^{-1}$, respectively.

Keywords: gas chromatography, lemon, pesticide residues, thiabendazole, imazalil

\section{Introduction}

Fungicides are used in the control of a wide range of fungal diseases on fruit, vegetable and ornamental cultures. The use of fungicides is performed during the growing season and after harvest time. However, the fungicides applied can leave chemical residue in cultures, which must not exceed maximum residue levels established for individual chemical.

In Brazil, thiabendazole and imazalil, which chemical structures are presented in Figure 1, have been used widely as a pre- or post-harvest systemic fungicide for the control of plant diseases for a wide variety of fruits, vegetables and other field crops. ${ }^{1}$

The most commonly analytical technique for analysis of thiabendazole and imazalil in fruits and vegetables is the high-performance liquid chromatography coupled with UV-vis and/or fluorescence detection. Gas chromatography with nitrogen-phosphorus detection (NPD) has been described for benzimidazole fungicides. Most of the methods described to determine thiabendazole and imazalil residues show solvent extraction followed by clean-up techniques, such as liquid-liquid partition, adsorption

*e-mail: mlucia@iq.unesp.br chromatography and gel permeation chromatography. ${ }^{2-10}$ However, some methods have shown slight modifications due to the introduction of the solid-phase extraction. ${ }^{11,12}$

The present work describes a rapid method for determining thiabendazole and imazalil residues in lemons (peel and pulp), besides verifying the influence of the matrix effect on the response of the thermionic specific detector for thiabendazole and imazalil.

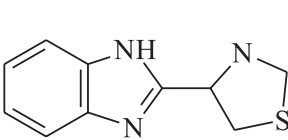

1

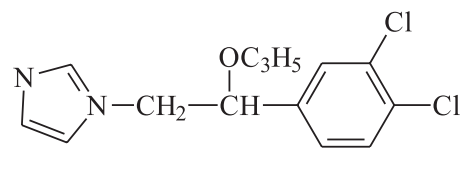

2
Figure 1. Thiabendazole (1) and imazalil (2) chemical structures.

\section{Experimental}

Chemicals

Ethyl acetate and hexane were nanograde (Mallinckrodt Baker Inc., Paris, Kentucky, USA) and 
checked for interfering residues by GC. Sodium chloride and anhydrous sodium sulfate were analytical grade (Mallinckrodt).

\section{Standards}

Reference standards of thiabendazole ( $99.9 \%$ pure) and imazalil (97.0\% pure) were obtained from Dr. Ehrenstorfer (Augsburg, Germany). Stock standard solutions were made up in methanol. The working solutions were prepared by appropriate dilution of stock solution in hexane:ethyl acetate $(1: 1, \mathrm{v} / \mathrm{v})$ at the concentrations of 0.2 to $10.0 \mathrm{mg} \mathrm{L}^{-1}$ to be used as standard and spiking solutions. The matrix standards were prepared using lemon extract into which were added thiabendazole and imazalil standard in different concentrations. All standard solutions were stored at $-18{ }^{\circ} \mathrm{C}$.

\section{Instrumentation}

Chromatographic analysis were carried out using a Varian 3300 gas chromatograph equipped with a thermionic specific detector (TSD), split-splitless injector and connected to a Varian 4290 reporting integrator. The capillary column was a DB-5 fused-silica column (30 m x $0.25 \mathrm{~mm}$ id, $0.25 \mu \mathrm{m}$; J\&W Scientific, Folsom, CA, USA). The injector and detector were operated at $240{ }^{\circ} \mathrm{C}$ and $300{ }^{\circ} \mathrm{C}$, respectively. Analytical solutions $(1.0 \mu \mathrm{L})$ were injected in the splitless mode (40 s), and the oven temperature was programmed as follows: $100{ }^{\circ} \mathrm{C}$ for $1 \mathrm{~min}$, increasing to $260{ }^{\circ} \mathrm{C}\left(10{ }^{\circ} \mathrm{C} \mathrm{min}^{-1}\right)$, and holding for $5 \mathrm{~min}$. Nitrogen (99.99\% pure) was used as carrier gas at $0.7 \mathrm{~mL} \mathrm{~min}^{-1}$. Detector gases: air: $189 \mathrm{~mL} \mathrm{~min}{ }^{-1}$, hydrogen: $1.5 \mathrm{~mL} \mathrm{~min}^{-1}$, nitrogen: $31 \mathrm{~mL} \mathrm{m^{-1 }}$.

\section{Sample preparation and fortification}

Lemon samples were peeled and cut with a stainlesssteel knife. Peel and pulp were homogenized separately using a household blender, and stored in closed glass flasks at $-18{ }^{\circ} \mathrm{C}$.

Fortified samples were prepared by adding $1.0 \mathrm{~mL}$ of standard solution of adequate concentration to $20.0 \mathrm{~g}$ of sample.

\section{Method}

An analytical sample of $5.0 \mathrm{~g}$ was weighed in a screwcapped flask. $10.0 \mathrm{~mL}$ hexane:ethyl acetate mixture (1:1, $\mathrm{v} / \mathrm{v})$ and $2.0 \mathrm{~g}$ sodium chloride were added and the flask was shaken for 20 min on mechanical shaker (Thermolyne,
Dubuque, Iowa, USA). The organic layer was poured into another flask containing $2.0 \mathrm{~g}$ anhydrous sodium sulfate, and $1.0 \mu \mathrm{L}$ was analysed by GC-TSD.

\section{Results and Discussion}

The method applied for the extraction of the thiabendazole and imazalil residues from lemons was based on the analytical method described for the determination of these fungicides in orange samples (peel and whole fruit). ${ }^{13}$

The ethyl acetate and sodium sulfate extraction method without further clean-up has been applied as a screening method for the analysis of pesticides in different matrices, yielding good recovery. ${ }^{14}$ Therefore, the mixture hexane:ethyl acetate $(1: 1, \mathrm{v} / \mathrm{v})$ was selected to extract thiabendazole and imazalil residues, because ethyl acetate has a high extraction yield and the hexane decreases the extraction of polar co-extractives. Furthermore, the ethyl acetate ensures the best penetration into the fruit sample and is able to form emulsion free interface.

The analytical procedure is simple and rapid. The method was applied separately to the peel and the pulp. The extraction recoveries for thiabendazole and imazalil residues were calculated for each part of the fruit. Despite not being edible, the lemon peel and its components are largely employed as raw material in food, pharmaceutical, cosmetic and animal food industries, so it is important to investigate the levels of thiabendazole and imazalil in this matrix. $^{15}$

To evaluate the efficiency of the method and the possibility of applying the method to real samples, the analytical characteristics of the method, linear response, detection and quantification limits and repeatability were investigated.

No interfering peaks were observed on the chromatograms of the different samples under the selected conditions. Figure 2 shows typical chromatograms of the control pulp lemon sample, standard solution of thiabendazole and imazalil and fortified pulp lemon extract $\left(0.5 \mathrm{mg} \mathrm{kg}^{-1}\right)$. The two fungicides were separated easily with the DB-5 column commonly used to determine pesticide residues. From the experiments performed using isothermal chromatography, it was observed that at lower temperature the fungicides were well separated but the analysis time was extended. The optimum results were obtained using the temperature program. The retention times of thiabendazole and imazalil were $9.10 \mathrm{~min}$ and $10.81 \mathrm{~min}$, respectively.

The efficiency of the extraction procedure was evaluated by means of the recovery of eight replicates of fortified 


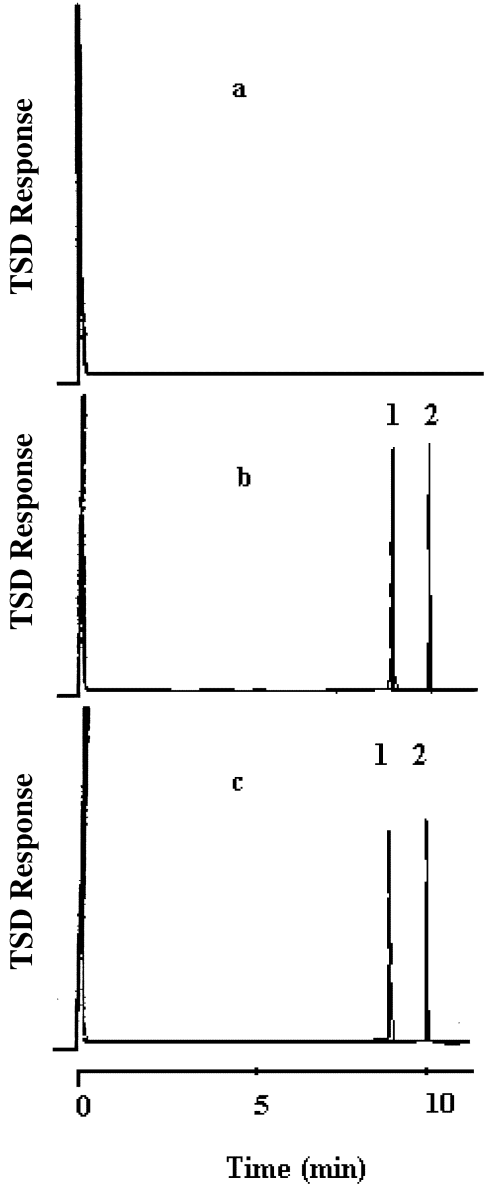

Figure 2. GC-TSD chromatograms: (a) control pulp lemon sample; (b) 1-thiabendazole $\left(\mathrm{t}_{\mathrm{r}}=9.10 \mathrm{~min}\right)$ and 2-imazalil $\left(\mathrm{t}_{\mathrm{r}}=10.81 \mathrm{~min}\right)$ standard solution, $0.5 \mathrm{mg} \mathrm{kg}^{-1}$; (c) fortified lemon pulp sample spiked with thiabendazole and imazalil, $0.5 \mathrm{mg} \mathrm{kg}^{-1}$. For conditions, see text. lemon samples (peel and pulp). Table 1 shows recoveries of two fungicides at three concentration levels. Mean recoveries ranged from $79 \%$ to $109 \%$, with values from $2.4 \%$ to $12.8 \%$ to relative standard deviation (R.S.D.), when considered that the solutions were prepared in ethyl acetate. The detection and quantification limits for the method were $0.2 \mathrm{mg} \mathrm{kg}^{-1}$ and $0.5 \mathrm{mg} \mathrm{kg}^{-1}$, respectively. ${ }^{16}$ The linearity of the thermionic specific detector for thiabendazole and imazalil ranged from 0.2 to $15.0 \mathrm{mg} \mathrm{kg}^{-1}$, with correlation coefficients between 0.9993 and 0.9995 .

Table 2 shows some difference between the method studied and the Yamazaki ${ }^{17}$ and Oishi ${ }^{18}$ methods. The comparison emphasizes the recuperation values, coefficients of variation, extraction and clean-up procedures. Also these methods require a large volume of solvent and large amount of sample. The present method has comparable results at the same level of concentration and emphasizes the reduced number of steps involved in the analytical procedure.

Few studies described in the literature report that $\mathrm{GC} /$ nitrogen-phosphorus detector response to some kind of pesticide and matrices can give anomalous recoveries. ${ }^{19-21}$ To verify this effect, the working solutions of the thiabendazole and imazalil standards were prepared in lemon residue-free extract, and their GC-TSD response was compared with the response at the same concentration of these standards in ethyl acetate. However, as presented in Table 1, the results of the assays show that no difference was noted in response to the thermionic specific detector between the standard in lemon extract and the standard in ethyl acetate. So it could be concluded that there is no matrix interference, since the

Table 1. Recoveries of thiabendazole and imazalil from fortified lemon samples: comparison of the standard prepared in solvent and in untreated lemon matrix

\begin{tabular}{|c|c|c|c|c|c|}
\hline \multirow{3}{*}{ Fungicide } & \multirow{3}{*}{$\begin{array}{c}\text { Spiked }{ }^{\mathrm{b}} \\
\text { level } \\
\left(\mathrm{mg} \mathrm{kg}^{-1}\right)\end{array}$} & \multicolumn{4}{|c|}{ Recovery $(\%)^{\mathrm{a}}$} \\
\hline & & \multicolumn{2}{|c|}{ Solvent } & \multicolumn{2}{|c|}{ Lemon extract } \\
\hline & & Range & Average (R.S.D.) & Range & Average (R.S.D.) \\
\hline \multirow{3}{*}{$\begin{array}{l}\text { Thiabendazole } \\
\text { (Peel) }\end{array}$} & 1.0 & $89-102$ & $94(5.4)$ & $85-98$ & $90(6.3)$ \\
\hline & 5.0 & $78-113$ & $97(12.8)$ & $80-103$ & $93(10.4)$ \\
\hline & 10.0 & $103-114$ & $109(3.8)$ & $98-105$ & $100(3.3)$ \\
\hline \multirow{3}{*}{$\begin{array}{l}\text { Thiabendazole } \\
\text { (Pulp) }\end{array}$} & 0.5 & $82-105$ & $94(7.7)$ & $80-100$ & $93(5.9)$ \\
\hline & 1.0 & $91-101$ & $95(3.6)$ & $89-97$ & $90(6.0)$ \\
\hline & 5.0 & $85-102$ & $92(6.9)$ & $84-93$ & $89(4.9)$ \\
\hline \multirow{3}{*}{$\begin{array}{l}\text { Imazalil } \\
\text { (Peel) }\end{array}$} & 1.0 & 94-111 & $103(6.1)$ & $89-105$ & $94(4.9)$ \\
\hline & 5.0 & $74-86$ & $79(5.7)$ & $83-93$ & $89(4.7)$ \\
\hline & 10.0 & $85-100$ & $92(6.9)$ & $90-100$ & $96(4.7)$ \\
\hline \multirow{3}{*}{$\begin{array}{c}\text { Imazalil } \\
(\mathrm{Pulp})\end{array}$} & 0.5 & $78-99$ & $88(6.6)$ & $80-90$ & $88(4.8)$ \\
\hline & 1.0 & $96-102$ & $99(2.4)$ & $89-101$ & $92(5.7)$ \\
\hline & 5.0 & $79-85$ & $83(4.1)$ & $79-90$ & $87(4.1)$ \\
\hline
\end{tabular}

${ }^{\mathrm{a}} \mathrm{n}=8$ replicates. ${ }^{\mathrm{b}}$ maximum residue limits in citrus fruit. ${ }^{1,22}$ Thiabendazole: $10.0 \mathrm{mg} \mathrm{kg}{ }^{-1}$. Imazalil: $5.0 \mathrm{mg} \mathrm{kg}^{-1}$. 
Table 2. Comparison of the literature methods and the present method for the determination of thiabendazole and imazalil in citrus fruit

\begin{tabular}{|c|c|c|c|c|}
\hline \multirow{2}{*}{$\begin{array}{l}\text { Fungicide } \\
{[\text { Matrix, g] }}\end{array}$} & \multirow{2}{*}{$\begin{array}{l}\text { Spiked level }\left(\mathrm{mg} \mathrm{kg}^{-1}\right) \\
\text { [Solvent, } \mathrm{mL}]\end{array}$} & \multicolumn{2}{|c|}{ Analytical procedure } & \multirow[t]{2}{*}{ Average (R.S.D.) } \\
\hline & & Extraction & Clean-up & \\
\hline Thiabendazole $^{\mathrm{a}}$ & 1.0 & $\begin{array}{c}10 \mathrm{~mL} \text { hexane: ethyl } \\
\text { acetate } \\
2 \mathrm{~g} \mathrm{NaCl}\end{array}$ & & $\begin{array}{c}94^{\mathrm{a}} \\
(5.4)\end{array}$ \\
\hline $\begin{array}{c}\text { Imazalil }^{\mathrm{b}} \\
{[\text { lemon peel, 5] }}\end{array}$ & {$[10]$} & $\begin{array}{c}\text { Shake for } 20 \mathrm{~min} \\
2 \mathrm{~g} \mathrm{Na}_{2} \mathrm{SO}_{4} \\
\text { GC-TSD }\end{array}$ & No clean-up & $\begin{array}{l}103^{b} \\
(6.1)\end{array}$ \\
\hline $\begin{array}{l}\text { Thiabendazole }^{c} \\
\text { [orange juice, 20] }\end{array}$ & $\begin{array}{l}1.0 \\
{[100]}\end{array}$ & $\begin{array}{c}0.2 \% \\
\text { phenolphthalein } \\
\mathrm{pH}=8-9(\mathrm{NaOH}, 2 \mathrm{M}) \\
\text { Dilute } 25 \mathrm{~mL} \text { of } \mathrm{H}_{2} \mathrm{O} \\
\text { Centrifuge, } 10 \mathrm{~min}\end{array}$ & $\begin{array}{l}\text { Extrelut column } \\
\text { Elution: } 100 \mathrm{~mL} \\
\text { hexano:ethyl acetate } \\
\text { Evaporate } \\
\text { GC-NPD }\end{array}$ & $\begin{array}{c}94 \\
(2.0)\end{array}$ \\
\hline $\begin{array}{l}\text { Imazalil d }^{\mathrm{d}} \\
\text { [lemon, 10] }\end{array}$ & $\begin{array}{l}1.0 \\
{[197]}\end{array}$ & $\begin{array}{c}50 \mathrm{~mL} \text { ethyl acetate } \\
30 \mathrm{~g} \mathrm{Na}_{2} \mathrm{SO}_{4} \\
3 \mathrm{~g} \mathrm{Na}_{2} \mathrm{CO}_{3} \\
\text { Blend for } 3 \mathrm{~min} \\
\text { Evaporate to dryness }\end{array}$ & $\begin{array}{c}\text { Diol cartridge } \\
\text { Elution: } 120 \mathrm{~mL} \\
\text { methanol } \\
\text { Evaporate to dryness } \\
\text { GC-NPD }\end{array}$ & $\begin{array}{c}92 \\
(1.9)\end{array}$ \\
\hline
\end{tabular}

a, b: present method, $n=8$ replicates; c: reference $17, n=3$ replicates; d: reference $18, n=5$ replicates.

analysis based on the matrix standard solution gave similar results (according to the experiments with standard solutions in ethyl acetate), yielding good values of recovery an R.S.D.. Therefore, the experiments with matrix standard solutions did not provide a more accurate quantification.

Due to the simplicity of this method, one can get rapid and inexpensive analysis of thiabendazole and imazalil residues in lemon sample (peel and pulp), using a thermionic specific detector.

\section{Conclusions}

The described procedure is simple and rapid. It was successfully applied to the extraction of thiabendazole and imazalil residues from lemons (peel and pulp). Precision and accuracy were very satisfactory for validation of the method. It can be emphasized that the results are in good agreement with literature data. Matrix interference was not observed in this work.

\section{References}

1. Gelmini, G.; Legislação Básica, Fundação Cargill: Campinas, 1991.

2. Roos, A.H.; Munsteren, A.J.V.; Nab, M.F.; Tuinstra, M.G.L.; Anal.Chim. Acta 1987, 196, 95.

3. Motohashe, N.; Nagashima, H.; Meyer, R.; J. Liq. Chromatogr. 1991, 13, 345 .

4. Motohashe, N.; Nagashima, H.; Meyer, R.; J. Liq. Chromatogr. 1991, 14, 3591.
5. Andersson, A.; Palsheden, H.; Freseniu's J. Anal. Chem. 1991, $339,365$.

6. Aguera, A.; Contreras, M.; Fernandez, A.; J. Chromatogr. 1993, 655, 293.

7. Valende, A.; Gonzalez, E.; Aguera, A.; J. Agric. Food Chem. 1991, 39, 2188.

8. Specht, W.; Pelz, S.; Gilsbach, W.; Freseniu's J. Anal. Chem. 1995, 353, 183.

9. Sicbaldi, F.; Sarra, A.; Mutti, D.; Bo, F.P.; J. Chromatogr. 1994, $765,13$.

10. Koineche, A.; Kreuzig, R.; Bahadir, J.; Siebers, J.; Nolting, H.G.; Freseniu's J. Anal. Chem. 1994, 349, 301.

11. Schirra, M.; Cabras, P.; Angioni, A.; Hallewin, G.D.; Ruggiu, R.; Minelli, E.V.; J. Agric. Food Chem. 1997, 10, 4127.

12. Steinwandter, H. In Emerging Strategies for Pesticide Analysis; Cairns, T.; Sherma, J., eds.; CRC Press: Boca Raton, Florida, 1992, p 3.

13. Navickiene, S.; Ribeiro, M.L.; J. High Resolut. Chromatogr. 1999, 22, 303.

14. Fletorius, D.; Botsoglou, N.; Psomas, J.; Mantis, A.; J. Assoc. Off. Anal. Chem. Inter. 1996, 79, 1281.

15. Silva, E.M.F. In Estudos sobre o Mercado de Frutas; Silva, E.M.F., ed.; FIPE: São Paulo, 1999, p. 343.

16. Thier, H.P.; Zeumer, H. In Manual of Pesticide Residue Analysis; Thier, H.P.; Zeumer, H., eds.; Deutsche Forchungsgemeinschat, Pesticide Comm. Verlag: Weinheim; New York, 1987, p. 37.

17. Yamazaki, Y.; Ninomiya, T.; J. Assoc. Off. Anal. Chem. Inter. 1996, 79, 787. 
18. Oishi, M.; Onishi, K.; Nakazawa, H.; Tanabe, S.; J. Assoc. Anal. Chem. Inter. 1994, 77, 1293.

19. Tjan, G.H.; Jansen, I.T.A.; J. Assoc. Anal. Chem. Inter. 1993, 638, 57.

20. Gillespie, A.M.; Walters, S.M.; Anal. Chim. Acta 1991, 245, 259.

21. Erney, J.; Holadová, K.; Kocourek, V.; Poustka, J.; Godula, M.; Cuhra, P.; Kempný, M.; J. Chromatogr. 1998, 800, 283.
22. Codex Alimentarius-Pesticide Residues in Food; Joint FAO/ WHO Food Standards Programme; Rome, 1998. http:// www.fao.org, accessed in July 2002.

Received: June 21, 2001

Published on the web: July 25, 2002

FAPESP helped in meeting the publication costs of this article. 